\title{
Program ÉTA Technologické agentury ČR
}

\author{
Hana Georgi
}

Technologická agentura ČR (TA ČR) připravuje na listopad tohoto roku 6. veřejnou soutěž programu na podporu aplikovaného společenskovědního a humanitního výzkumu, experimentálního vývoje a inovací ÉTA, viz https://www.tacr.cz/program/program-eta .

Program podpoří zapojení společenských a humanitních věd do projektů aplikovaného výzkumu a inovací, které jsou př́nosné pro udržení a zvyšování kvality života člověka v reakci na dynamické společenské, ekonomické, globalizační, kulturní nebo technologické proměny. Program ÉTA je v reakci na světové události v souvislosti s pandemií covid-19 pozměněn tak, aby bylo možné v letošním roce tuto 6 . soutěž otevřít. Základními změnami jsou: prodloužení programu, navýšení výdajů programu a umožnění realizace jako součást Národního plánu obnovy (NPO).

Na vědu, výzkum a inovace (VVI), tedy jeden ze 6 pilírư NPO, bude v NPO alokováno 6,9 \%. Celkem půjde o 13,2 mld. Kč bez DPH (k 22. 7. 2021), viz https://www.planobnovycr.cz/ . Celková alokace finančních zdrojů určených pro 6. soutěž ÉTA zatím není známa. Bude se odvíjet od podrobnějšího členění rozpočtu NPO na VVI.

První soutěž programu ÉTA byla otevřena v roce 2017 a zatím poslední pátá v roce 2020. Alokované částky na jednotlivé soutěže byly od 100 do 580 mil. Kč. Vývoj počtu podaných projektů (graf 1) a míry úspěšnosti danou poměrem počtu podpořených projektů ku počtu projektů přijatých do hodnocení (graf 2) ukazuje kolísání počtu projektů, ale sestupnou tendenci míry úspěšnosti.

Pro srovnání, míra úspěšnosti standardních projektů základního výzkumu podpořených Grantovou agenturou ČR (GA ČR) s počátkem řešení v roce 2020 byla $25,4 \%$. Oproti předchozímu roku došlo $\mathrm{k}$ poklesu o 6,4 procentních bodů, z původní $31,8 \%$ úspěšnosti v roce 2019. Nízká úspěšnost byla v GA ČR zaznamenána v letech 2013 a 2014, kdy byla v průměru pouze 17,5 \% (Zpráva o činnosti Grantové agentury České republiky za rok 2019, s. 15; https://gacr.cz/o-ga-cr/pro-media/zpravy-o-cinnosti/ ). 


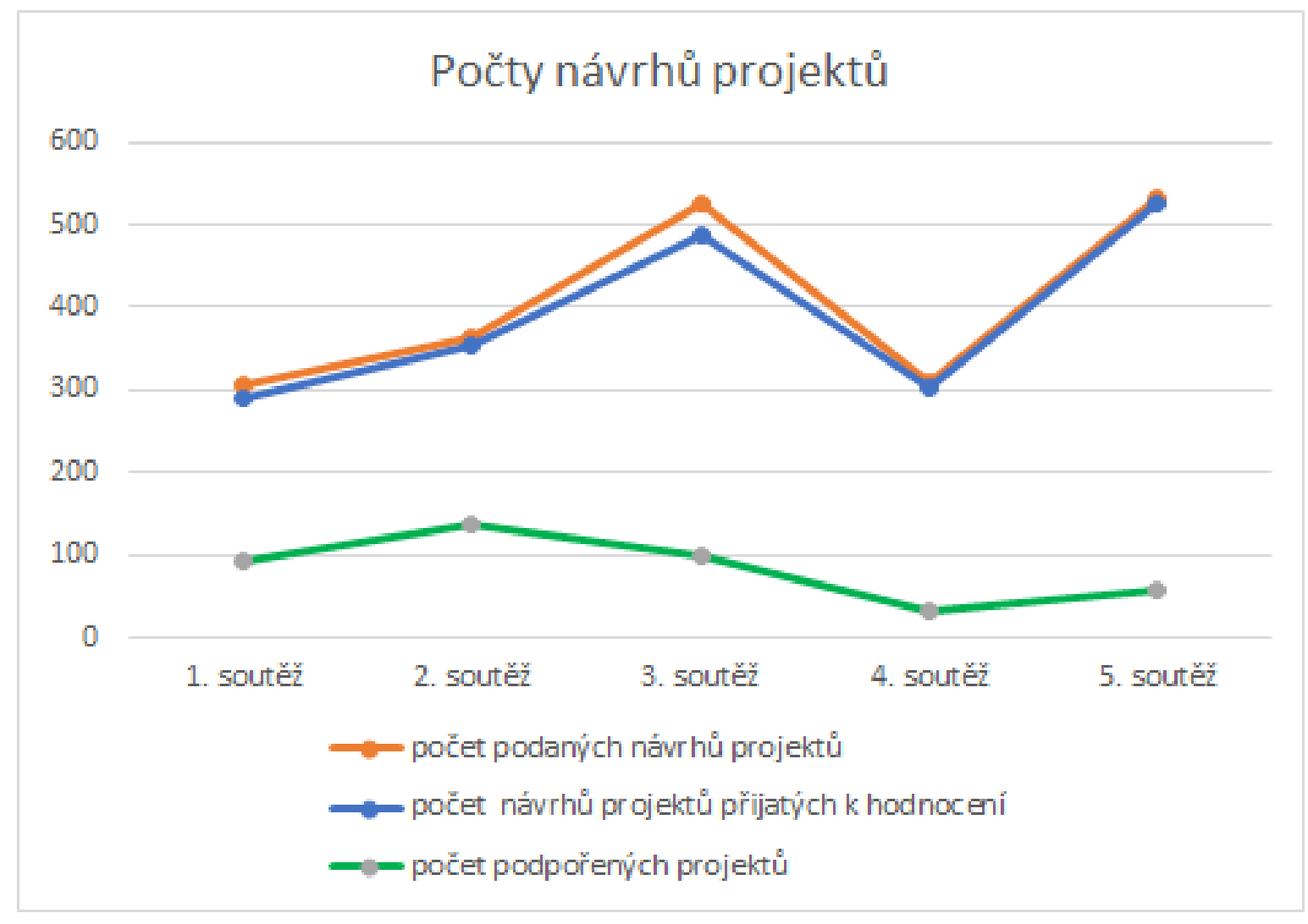

Graf 1.

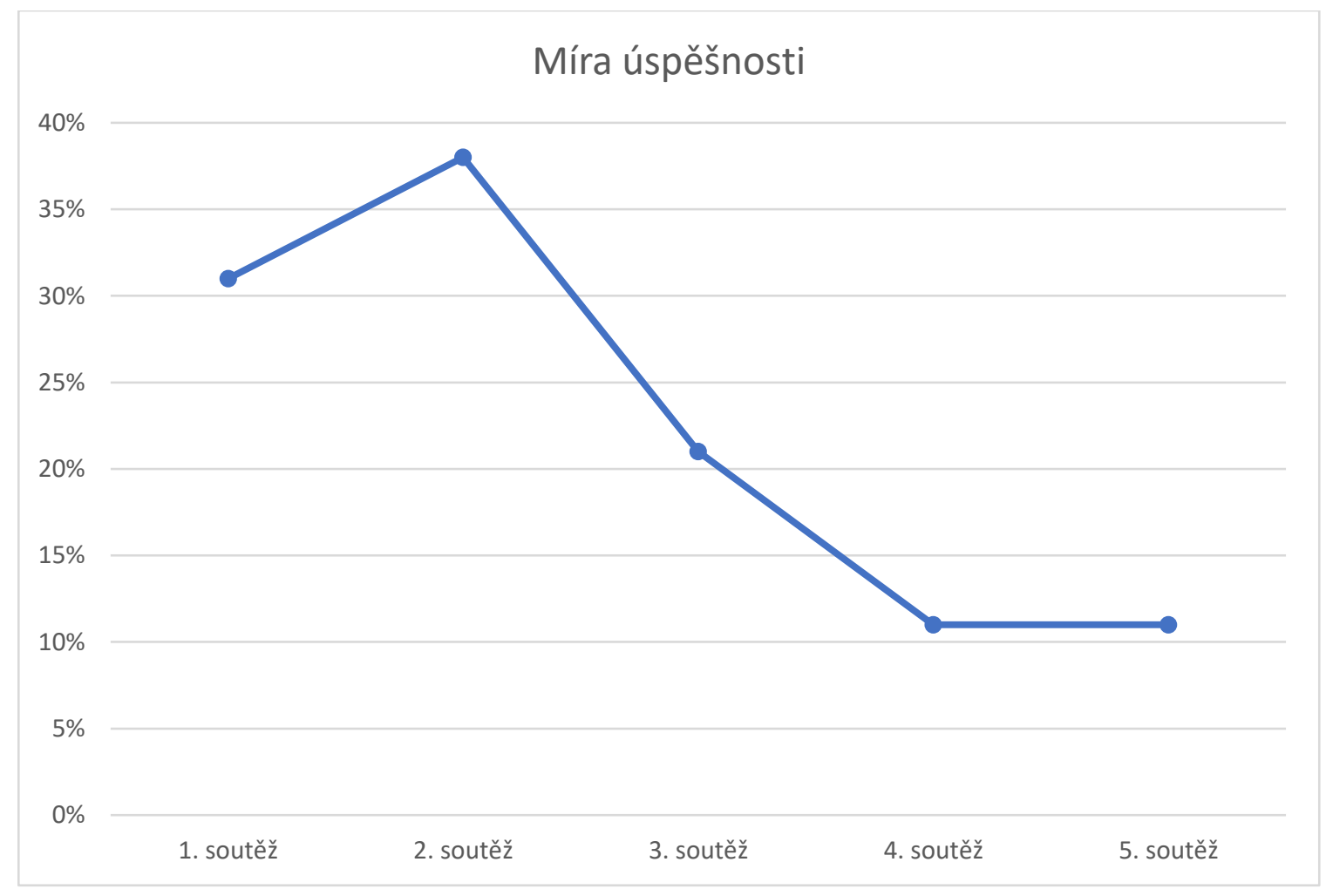

Graf 2. 
Užitečným nástrojem pro žadatele je zpracování nejčastějších důvodů k nedoporučení návrhů projektů k podpoře, které na svém webu TA ČR publikuje vždy na základě zkušeností s další výzvou https://www.tacr.cz/program-eta-nejcastejsi-duvody-k-nedoporuceni-navrhu-projektuk-podpore-v-5-verejne-soutezi/

Níže uvádíme př́iklady úspěšných projektů v programu ÉTA běžících od roku 2021:

Název projektu: Nástroj pro zkoumání vlivu osobnostních charakteristik a vnějších faktorů na dynamiku týmu při dlouhodobém pobytu v ICE environment. Př́ijemce: České vysoké učení technické v Praze / Fakulta strojní, řešitel: Ing. Michal Schmirler, PhD. (Odkaz CEP)

Název projektu: Komplexni systém psychologické ponehodové péče v ČR. Př́ijemce: Centrum dopravního výzkumu, v.v.i., řešitelka: Mgr. Darina Havlíčková. (Odkaz CEP)

Název projektu: Diagnostický nástroj pro posouzení vývoje komunikace u českých dètí od 8 do 30 měsíců. Př́ijemce: Psychologický ústav AV ČR, v. v. i., řešitelka: Mgr. Nikola Paillereau, Ph.D. (Odkaz CEP)

Název projektu: Zvýšeni kvality života v domovech pro seniory v obdobi nouzového stavu. Př́ijemce: České vysoké učení technické v Praze / Fakulta biomedicínského inženýrství, řešitel: prof. MUDr. Leoš Navrátil, CSc., MBA, dr.h.c. (Odkaz CEP)

Název projektu: Aplikace pro rozvoj sociálnich kompetencí osob se závislostí v kontextu indikace speciálně pedagogické a terapeutické intervence. Př́ijemce: Univerzita Palackého v Olomouci / Pedagogická fakulta, řešitel: doc. Mgr. Michal Růžička, Ph.D. (Odkaz CEP)

Název projektu: Brain circulation jako pilír možné transformace strukturálně postiženého regionu. Př́jemce: Univerzita Jana Evangelisty Purkyně v Ústí nad Labem / Fakulta sociálně ekonomická, řešitelka: PhDr. Alice Reissová, Ph.D. (Odkaz CEP)

Pro aktuální informace o soutěži sledujte web TA ČR. Přejeme všem navrhovatelům projekti̊ nosné nápady a hodně štěstí v soutěži.

Aktualizace z 21. 10. 2021

Veřejná soutěž nebude vyhlášena $\mathrm{v}$ plánovaném termínu, informace o dalším postupu budou na stránkách TA ČR. [zdroj: TA ČR]

\section{Údaje o autorce}

PhDr. Hana Georgi, Ph.D. působí na Pražské vysoké škole psychosociálních studií jako prorektorka pro výzkum. Jejím vědeckým zájmem je geropsychologie, zastupuje Českou republiku v SC on GeroPsychology EFPA a je spoluzakladatelkou sekce geropsychologie př̀ ČMPS.

Kontakt: hana.georgi@pvsps.cz

Georgi, H. (2021). Program ÉTA Technologické agentury ČR. E-psychologie, 15(3), 32-34. https://doi.org/10.29364/epsy.413 